\title{
Effects of Borıc Acid Additive to Pumice Aggregate Lightweight Concrete Properties
}

\author{
Halil Tezel \\ Department of Civil Engineering, Institute of Science and Technology, \\ Kastamonu University, Kastamonu, Turkey \\ E-mail: htezel25@gmail.com \\ Hakan Caglar \\ Department of Civil Engineering, Faculty of Engineering and Architecture, \\ Kastamonu University, Kastamonu, Turkey \\ E-mail: hcaglar@kastamonu.edu.tr \\ Arzu Caglar \\ Department of Building Control, Abana Sabahat Mesut Yilmaz Vocational High School, \\ Kastamonu University, Kastamonu, Turkey \\ E-mail: arzuyilmaz@kastamonu.edu.tr \\ Omer Can (Corresponding author) \\ Department of Civil Engineering, Faculty of Engineering, \\ Bayburt University, Bayburt, Turkey \\ E-mail: ocan@bayburt.edu.tr \\ Selcuk Cimen \\ Department of Civil Engineering, Faculty of Engineering, \\ Bayburt University, Bayburt, Turkey \\ E-mail: selcukcimen@ogr.bayburt.edu.tr
}

\begin{abstract}
Pumice aggregates are used in the production of lightweight concretes due to their low density, good thermal and sound insulation characteristics as well as their admirable resistance against elevated temperatures. In this study, the effects of boric acid addition to pumice aggregate lightweight concrete at different ratios (Ref: $0 \%, 2 \%, 4 \%$ and 6\%) were investigated. For this purpose; physical (dry unit weight, water absorption and porosity) and mechanical (compressive strength, tensile splitting strength) tests on produced lightweight concrete samples by boric acid-doped pumice aggregates were performed. Furthermore, SEM images were employed in the clarification (plainly) of the microstructure of produced boric acid-doped lightweight concrete (microstructure properties). As a result of this study, it was observed that the physical properties such as porosity and water absorption values decreased while the dry unit weight increased. Moreover, an increase in compressive strength and tensile splitting strength values of produced lightweight concrete was observed. SEM images were examined and the best results were obtained from the addition of boric acid at $6 \%$ ratio. Therefore, it was determined that the use of boric acid as an additive in the production of lightweight concrete improved (significantly) the physical and mechanical properties of the produced lightweight concrete.
\end{abstract}

Keywords: Boric Acid, Pumice, Lightweight Concrete, Scanning Electron Microscope (SEM).

DOI: $10.7176 /$ JSTR/6-09-01

\section{Introduction}

Humankinds need shelter to protect themselves from environmental conditions and feel safe thus the need of various structures. The most crucial, principle and indispensable elements of these structures are construction materials. The structure which is described as economical, durable and of good quality is built on material base. based on the quality of the materials used in the construction of structures and their suitable usage, the life-span of structures can be increased [1]. The construction material which acts 
as bridge between construction technology and construction industry and whose usage rate is most common world widely, is concrete [2]. Concrete is an homogeneous construction material obtained by mixing at appropriate ratios water, aggregate, cement and, sometimes when required, additives such as mineral or chemical in determined amounts and ratios [3]. Depending on its usage purpose, concrete can be produced in various types with inherited various properties. The factors influencing the common and wide usage of concrete are: the abundance of raw materials used in its production, the facility and possibility to be shaped into different forms, sufficient high strength and its relatively low cost , furthermore concrete does not require much maintenance works [4] Together with advancing and evolving technology, developments have occurred in the concrete industry. These developments in the concrete industry, have given way to new range of concrete types known as special concretes in concrete technology. Special concretes are designed and manufactured for the purpose of fulfilling various special needs intended for their use according to their inherent special properties [5]. One of the special concrete types is known as lightweight concrete. During its production, minerals and chemical additives are used [6]. Lightweight concrete provides better insulation characteristics, low weight, enough strength and non-flammability advantages compared to conventional concrete. Moreover Lightweight concrete is an excellent solution in decreasing dead loads of structures [7]. Due to the facts that lightweight concrete is a lighter material which contribute significantly in decreasing both the totalweight and lateral loads of structures, it is regarded asan advantegeous concrete type [8,9]. The greatest feature which distinguishes lightweight concrete from conventional concrete is its lightness and forming of pores which provide better sound and heat insulation characteristics. These pores in the matrix are obtained by using porous aggregate such as pumice stone, slag, expanded clay, volcanic tuff, perlite etc., by the forming of porous microstructure or producing foam in fine mortar (bims) [10]. The most used technique in the production of lightweight concrete is by using porous aggregates. Generally, in lightweight concrete production, two types of aggregates which are natural (pumice, diatomite, volcanic fastener etc.) and artificial (perlite, clay, sintered fly-ash, expanded shale, etc.) are used [11]. When previously performed studies are examined, it is observed that lightweight concrete is produced generally by using pumice which a commonly known natural aggregate. The reason is that pumice has an inherent porous structure and resistance against physical and chemical factors. Thanks to its porous structure, pumice which has the properties of being light and good insulation is the most preferred aggregate type in the manufacturing of lightweight concrete [12].

A vast number of publications on lightweight concrete production by using different lightweight aggregate and mixture ratios are available. Beycioğlu et al. carried out various experiments to determine the fastening performance of lightweight concrete which was produced by using pumice aggregates coated with colemanite-cement paste [13]. As a result of the study, they reported that colemanite-cement coated pumice aggregate increase significantly the compressive strength of lightweight concretes and fastening performance.

Bideci manufactured lightweight concrete by coating the pumice aggregate surface with cement + colemanite binary mixtures $(0 \%, 7.5 \%, 12.5 \%$ and $17.5 \%)$. In the study, the produced samples were exposed at $20{ }^{\circ} \mathrm{C}$ (Control), $200{ }^{\circ} \mathrm{C}, 400{ }^{\circ} \mathrm{C}$ and $600{ }^{\circ} \mathrm{C}$ (temperatures) then unit weight, compressive strength, ultrasonic pulse rate and loss of weight from concrete samples were determined. As a result of the study, the optimum value of $12.5 \%$ was obtained from cement + colemanite samples. It was reported that lightweight concrete produced with pumice aggregates coated with cement + colemanite binary mixture showed high performance against elevated temperatures [14]. Hameed and Ahmed examined the compression, deflection and tensile strengths of lightweight concrete which they produced by using plastic waste. They determined that that an increase in compression, deflection and tensile strengths occurred together with increasing content of wastes , [15]. Hooi and Min (2017) produced lightweight concrete by using waste glass materials, and as a result, they reported that the waste at $20 \%$ ratio could be used as pozzolanic additive material [16].

Attanasio et al. (2015) have produced non-load-bearing lightweight concrete by using three types plastic scrap consisting of polyurethane foams, rubber and scraps arising from separating recycled plastics from solid urban waste. As a result of the study, it was determined that using recycled plastic aggregates decreased the lightweight concrete densities (density), and heat conductivity while exhibiting sufficient mechanical strengths [17]. Senhadji et al. (2015) produced lightweight concrete samples by using PVC plastic waste at $30 \%, 50 \%$ and $70 \%$ ratios instead of sand and coarse aggregate. According to data obtained as a result of the study, they reported that the produced samples fall into the category of structural lightweight concrete in terms of weight per unit of volume and strength [18]. Demirbaş and Karslığlu (1995) examined the effects of boric acid mixtures such as reactor waste, borogypsum and slurry on Portland cement compressive strength in their studies. As a result, it was observed that when the percent of the slurry in cement mixture increased the compressive strength decreased [19].

2 I P a g e www.iiste.org 
Koumpouri and Angelopoulos (2016) researched the effect of boric acid addition on low-energy belite cement manufacturing in their study and stated that boric acid in controlled amounts can be beneficial on belite cement manufacturing [20].

After the examination of previous studies on lightweight concrete it was observed that the use of boric acid and its effects on the production of lightweight concrete has yet to experimented upon. For this purpose, in this study, an experimental study on pumice aggregate as aggregate in lightweight concrete manufacturing and boric acid as additive was carried out. Within this scope, the usage of boric acid as a mineral additive aimed at improving physical, mechanic and micro-structure of lightweight concrete.

\section{Material And Method}

\subsection{Material}

\subsubsection{Pumice}

Pumice used in this study was obtained from Metal Mining Ltd. company operating in the region of Nevşehir/Çardak, Turkey. According to mineral research and exploration data, in Çardak region, proved reserve of $82.612 .500 \mathrm{~m}^{3}$, potential reserve of $87.592 .000 \mathrm{~m}^{3}$ and possible reserve of $68.445 .000 \mathrm{~m}^{3}$ in good quality is available [21]. The grain size of pumice aggregate used for concrete mix is $8 / 16 \mathrm{~mm}$ and $4 / 8 \mathrm{~mm}$ screen opening. Table 1 presents chemical properties of pumice aggregate used in experiments.

Table 1 Chemical analysis of pumice aggregates and Physical properties of natural sand

\begin{tabular}{ccccccc}
\hline \multicolumn{7}{c}{ Chemical Properties of pumice aggregates } \\
\hline Components (\%) & $\mathrm{SiO}_{2}$ & $\mathbf{A l}_{2} \mathbf{O}_{3}$ & $\mathbf{F e}_{2} \mathbf{O}_{3}$ & $\mathbf{C a O}$ & $\mathbf{M g O}$ & $\mathbf{K}_{2} \mathbf{O}$ \\
Rate (\%) & 74.10 & 13.45 & 1.40 & 1.17 & 0.35 & 4.10 \\
\hline \multicolumn{7}{c}{ Physical Properties of natural sand } \\
\hline Specific Gravity & 2.63 \\
Water absorption (\%) & 1,5 \\
\hline
\end{tabular}

\subsubsection{Sand}

Ankara province stream sand was used as fine aggregate in the production of lightweight concrete (mix). Aggregate size is in the range of $0 / 4 \mathrm{~mm}$. Table 1 presents physical properties of this natural sand.

\subsubsection{Cement}

CEM I 42,5 type cement produced by Nuh Cement factory which is in Hereke District of Kocaeli province was used. Table 2 presents physical and chemical properties of cement used.

Table 2 Properties of cement used in experiments

\begin{tabular}{|c|c|c|c|c|}
\hline \multirow{2}{*}{$\begin{array}{l}\text { Chemical Composition \% } \\
\text { Component }\end{array}$} & \multicolumn{4}{|c|}{ Physical and Mechanical Properties } \\
\hline & CEM I 42,5R & Specific Gravity & & 3.19 \\
\hline $\mathrm{CaO}$, total & 63.41 & Fineness Blaine $\left(\mathrm{cm}^{2} / \mathrm{gr}\right)$ & & 3654 \\
\hline $\mathrm{CaO}$, free & 1.2 & Compressive Strength (MPa) & 2- days & 29.8 \\
\hline $\mathrm{SiO}_{2}$, total & 20.22 & & 7- days & 49.6 \\
\hline $\mathrm{Al}_{2} \mathrm{O}_{3}$ & 5.67 & & 28- days & 61.1 \\
\hline $\mathrm{Fe}_{2} \mathrm{O}_{3}$ & 2.91 & & & \\
\hline $\mathrm{MgO}$ & 0.96 & & & \\
\hline $\mathrm{SO}_{3}$ & 2.92 & & & \\
\hline $\mathrm{Na}_{2} \mathrm{O}$ & - & & & \\
\hline $\mathrm{K}_{2} \mathrm{O}$ & - & & & \\
\hline $\mathrm{Mn}_{2} \mathrm{O}_{3}$ & - & & & \\
\hline $\mathrm{TiO}_{2}$ & - & & & \\
\hline Loss of ignition & 3.32 & & & \\
\hline Insoluble residue & 0.93 & & & \\
\hline
\end{tabular}

\subsubsection{Boric Acid}

Boric acid is an additive produced from colemanite, it has a financial value and is used actively in a number of industries. Boric acid which has white colour and solid phase was taken from Sigma Aldrich Company and its properties are presented in Table 3 and The preparation of boric acid solution is given in Fig 1. 


\subsubsection{Mixing Water}

Lightweight concrete mixing water used in this study was tap water provided by Ankara province.

Table 3 Properties of boric acid [22].

\begin{tabular}{lrr}
\hline Chemical Properties & Unit & Value \\
\hline Molecular Weight & $\mathrm{g} / \mathrm{mol}$ & 61.83 \\
Specific Gravity $\left(20^{\circ} \mathrm{C}\right)$ & $\mathrm{g} / \mathrm{cm}^{3}$ & 1.44 \\
Melting Point & ${ }^{\circ} \mathrm{C}$ & 171 \\
Heat of Formation & $\mathrm{kJ} / \mathrm{mol}$ & -1089 \\
$\mathrm{~B}_{2} \mathrm{O}_{3}$ Content & $\%$ & 56.3 \\
Heat of Solution & $\mathrm{kJ} / \mathrm{mol}$ & 22.2 \\
Boiling Point & ${ }^{\circ} \mathrm{C}$ & 300 \\
Water Solubility $\left(20^{\circ} \mathrm{C}\right)$ & $\mathrm{g} / 100 \mathrm{ml}$ & 4.72 \\
\hline
\end{tabular}
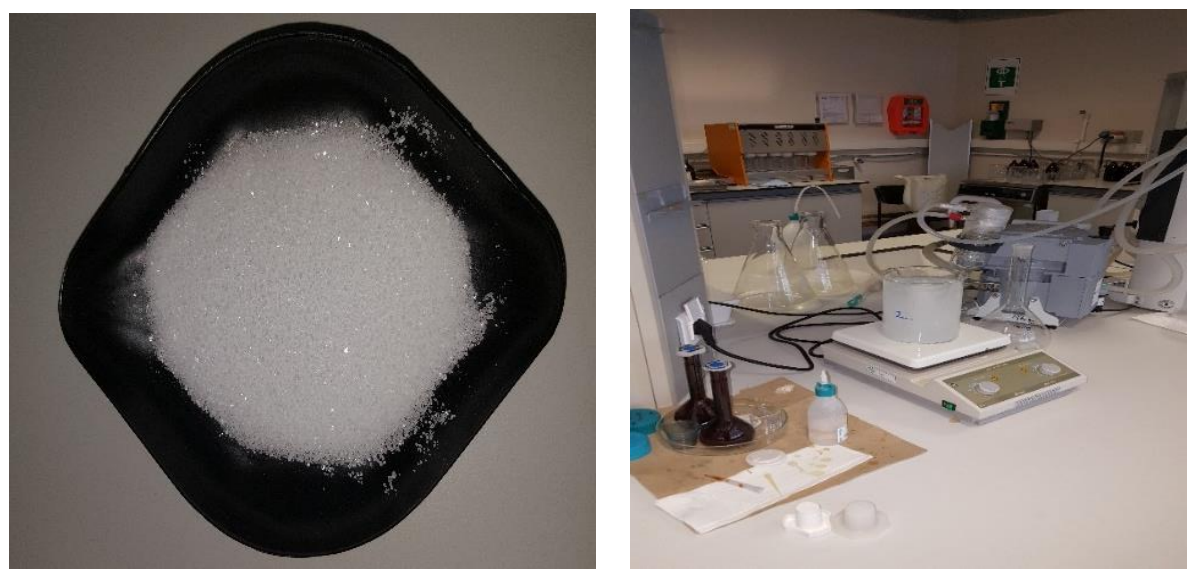

Figure 1 Preparation of boric acid solution

\subsection{Method}

\subsubsection{Manufacturing Of Boric Acid-Doped Lightweight Concrete}

In the study, samples from 4 different series of lightweight concrete mixtures (REF; reference sample, BA2; boric acid-doped sample at $2 \%$ rate, BA4; boric acid-doped sample at $4 \%$ rate, BA6; boric aciddoped sample at $6 \%$ ratio) were produced. The Mixing design of the produced samples is presented in Table 4. Water/cement ratio used was kept between 0,25-0,35. Boric acid additive was initially mixed with mixing water before being used for the production of lightweight concrete samples. Furthermore, pumice at $90 \%$ ratio was used in the production of reference samples. In order to increase the strength of lightweight concrete, sand at $10 \%$ ratio was added into the mix. The mixing and placement of lightweight concrete materials is shown in Fig 2.

Table 4 Rates of aggregates and boric acid used for lightweight concrete manufacture

\begin{tabular}{cccc}
\hline & Pumice (P) (\%) & Sand (\%) & Boric Acid (BA) (\%) \\
\hline REF & 90 & 10 & 0 \\
BA2 & 90 & 10 & 2 \\
BA4 & 90 & 10 & 4 \\
BA6 & 90 & 10 & 6 \\
\hline
\end{tabular}



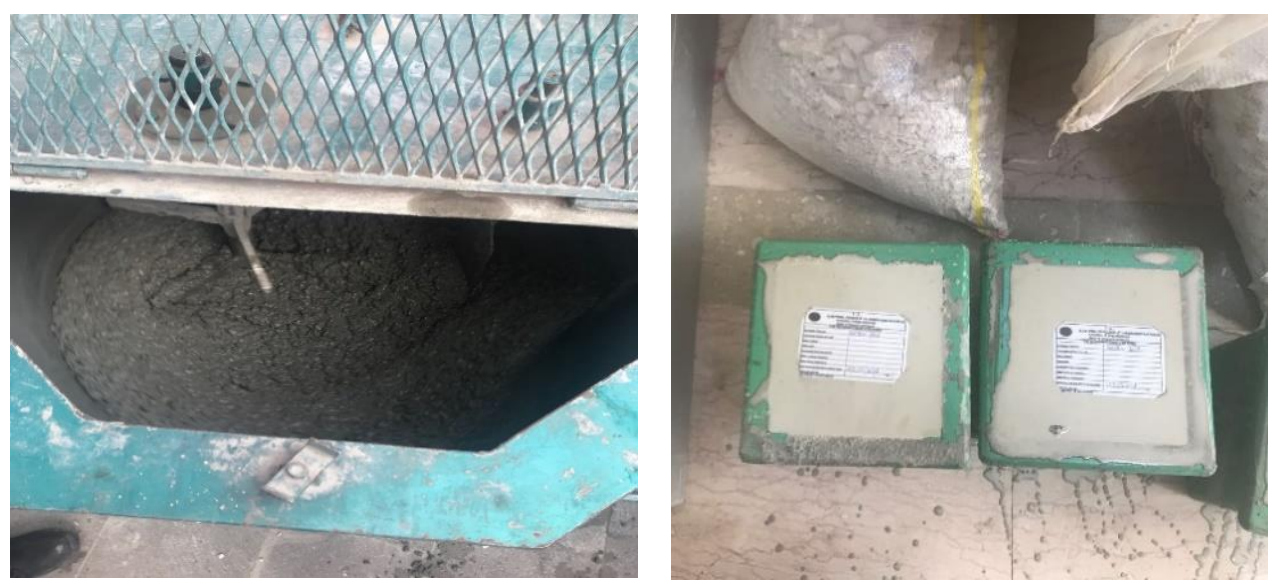

Figure 2 Mixing and placing lightweight concrete materials

The mixes were produced by conforming to TS 2511 standard [23]. Preliminary tests on pumice to be used as lightweight aggregate were performed according to the above-mentioned standard. Before the mixing process, the initial preparation of solution was realised by adding boric acid into $80{ }^{0} \mathrm{C}$ heated mixing water mixing with and. before being mixed with cement, pumice aggregates were pre-saturated. The pre-saturation of pumice aggregates was realized by soaking them into designated amount of water previously poured into the mix container. After the pre-saturation process, sand in the form of fine aggregate at $10 \%$ rate was added and stirred in order to obtain a homogeneous aggregate mix. The cement content determined in the mix design was added to obtained a well homogenous mixture. Finally, boric acid solution was added to the determined water content and the mixing process was continued. When the mix became homogeneous, the mixing process was finalized.

After the process was completed, the slurry was poured into $15 \times 15 \times 15 \mathrm{~cm}^{3}$ plastic cubic and cylinder moulds for tensile splitting strength, the fresh mixture was compacted so as to get rid of air voids thus reducing porosity and improve the strength of the samples. After compaction and placement process, lightweight concrete samples were kept in moulds until the final setting was completed ( 24 hours later). Lightweight concrete samples were demoulded after 24 hours and were soaked in the curing pools at $+20^{\circ} \mathrm{C}$ for curing process for 28 days. After 28 days, different experiments were performed on the lightweight concrete samples in order to determine their physical and mechanical properties.

\section{Results And Discussion}

\subsection{Dry Unit Weight}

When the dry unit weight values of lightweight concrete samples comprised of reference, boric aciddoped at $2 \%$ ratio (BA2), boric acid-doped at $4 \%$ ratio (BA4), boric acid-doped at $6 \%$ ratio (BA6) were compared (Figure 3), it was observed that while the reference sample had the lowest dry unit weight of $993 \mathrm{~kg} / \mathrm{m} 3$, boric acid-doped samples with $6 \%$ ratio had the highest value of $1010 \mathrm{~kg} / \mathrm{m} 3$. thus the determination that the dry unit weight of the samples increased as the amount of boric acid added into the mixture increased.

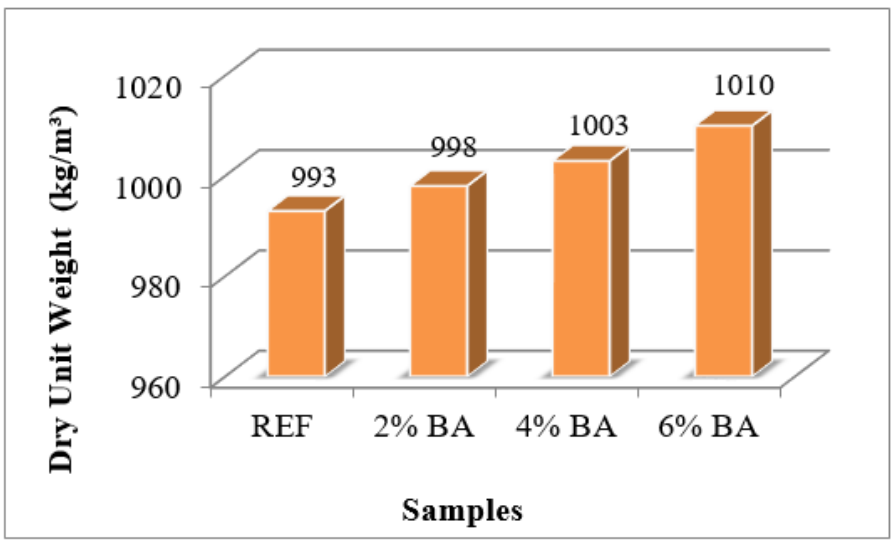

Figure 3 Dry unit weight of samples 


\subsection{Water Absorption}

Water absorption rate of lightweight concrete is related to the porosity of a given material. Although concrete is solid, it contains all sizes of seen or unseen, continuous or discontinuous pores. These pores within the internal structure effects significantly the durability and strength properties of concretes [24]. When Figure 4, which shows water absorption values of lightweight concrete samples is examined, it is observed that while the lowest water absorption was obtained from $6 \%$ ratio boric acid-doped samples, the highest water absorption was observed from the reference sample. Consequently, of the performed water absorption test, it was observed that water absorption decrease when the content boric acid increases. It is thought that the reason of this decrease is that boric acid filled the pores within the internal structure of the lightweight concrete samples.

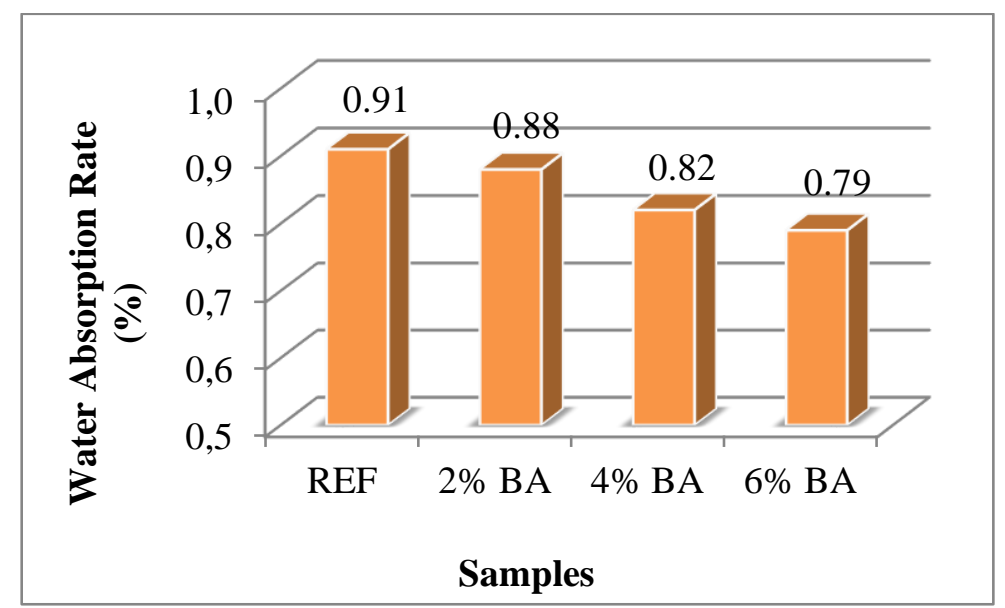

Figure 4 Water absorption rates of samples

Öztürk (2012) reported that the lowest water absorption rate of lightweight concrete samples which was produced by mixing pumice aggregate obtained from Nevşehir region at $90 \%$ ratio and sand aggregate at $10 \%$ was $0.7 \%$ [25] which are compatible with the results obtained in our present study.

\subsection{Porosity}

Figure 3 presents porosity values of lightweight concrete sample which was produced from pumice aggregate. When Figure 5 is examined, it is observed that the reference sample had the highest porosity value and the lightweight concrete samples doped with boric acid- at $6 \%$ ratio have the lowest porosity value. It was observed that when boric acid amount added into the mixture increases, the porosity values decreases. The reason of this is attributed to boric acid filling the pores within the lightweight concrete samples. The decrease of porosity rate means the decrease of water absorption amount and this situation maintains comfort conditions at desired level as well as prolonging life span of lightweight concrete structures.

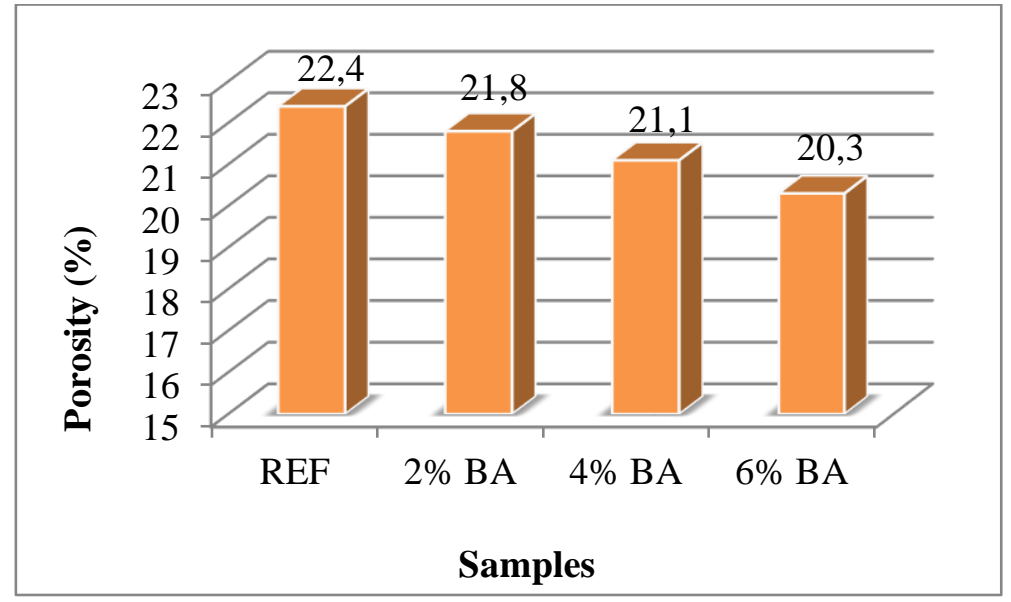

Figure 5 Porosity values of samples. 


\subsection{Compressive strength}

When the compressive strength comparison chart given in Figure 6 is examined, it is observed that when the boric acid amount increases, the compressive strength also increases. It was observed that the lowest pressure strength of 16.3 MPa belonged to the reference sample, and the highest pressure strength of 18.5 MPa belonged to $6 \%$. doped boric acid- samples In light of the data obtained as a result of the compression experiment, it is concluded that the lightweight concrete samples produced by using pumice aggregate obtained from Nevşehir region have strength values that are above those of required by ACI 213R-87 [27] for lightweight concrete (17.2 MPa). These results obtained show that the ratios specified in the present study can be easily used in the production of lightweight concrete.

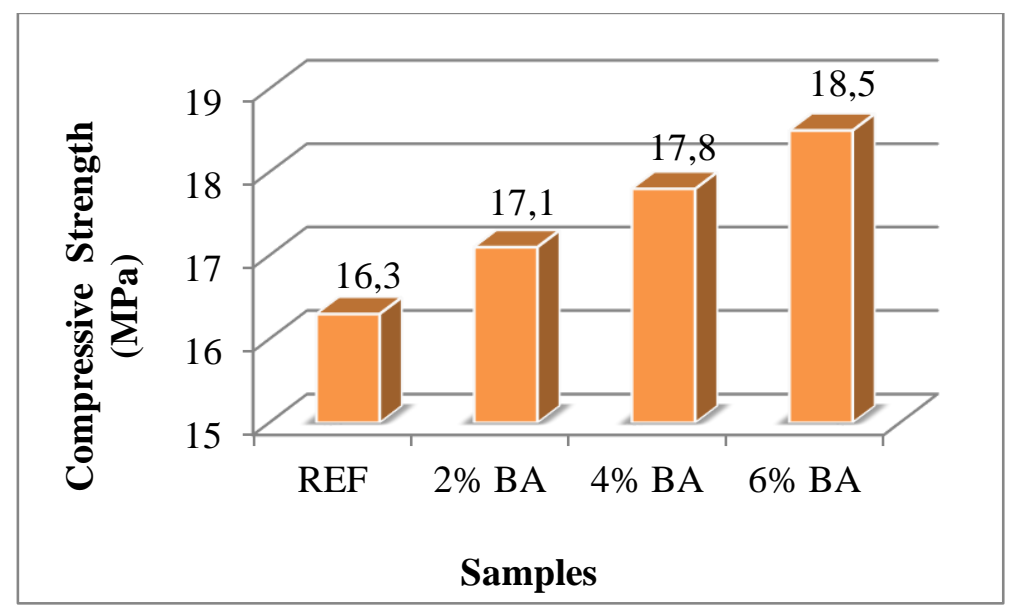

Figure 6 Compressive strength of samples

When the literature studies are examined, it was reported that 7 days compressive strength of concretes produced by using pumice belonging to Akçakale (2010), Osmaniye and Nevşehir region was between 4.9-16.3 MPa [27]. Hossain et al. (2011) reported that the compressive strength of lightweight concrete samples produced by using only coarse and fine pumice aggregates is lower than the strength obtained when sand at $10 \%$ is added [28].

\subsection{Tensile Splitting Strength}

Figure 7 shows tensile splitting strength values for the produced lightweight concrete samples. When the figure is examined, it is observed that the highest tensile splitting strength value belonged to the boric acid sample at $6 \%$ ratio, while the lowest value belonged to the reference sample. it has been determined that tensile splitting strength increases when the amount of boron waste increases.

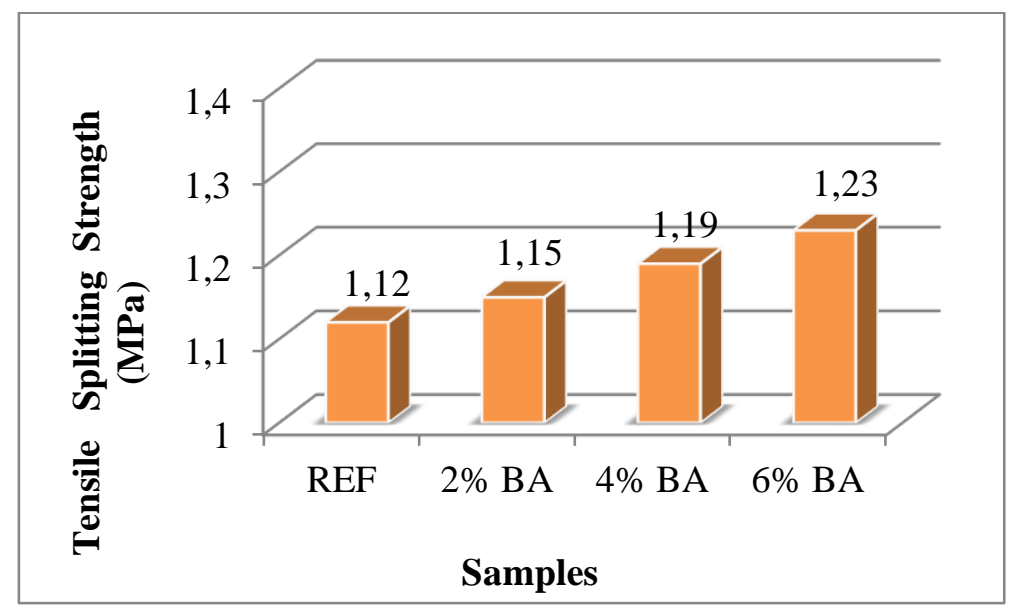

Figure 7 Tensile splitting strength of samples

Dikici (2010) reported that 7-days tensile splitting strength of the load-bearing lightweight concrete produced within the scope of his work was $2 \mathrm{MPa}$, at 28-days tensile splitting strength was $2.3 \mathrm{MPa}$ and at 56-days it was $2.4 \mathrm{MPa}$ [29]. 


\subsection{SEM Images of Lightweight Concrete Samples}

A regular cellular structure and crystal structure are The most important and desired property of lightweight concrete composites. Figure 8 shows that the sample of lightweight concrete produced with pumice aggregates obtained from Nevşehir region is of macro-cellular and irregular crystal structure. It is thought that this macro-cellular and irregular crystal structure derive from the porous structure of the pumice aggregates. This is the main reason for the lower the compressive strength of Lightweight Concrete composites. SEM images taken for the determination of structural characteristics of reference $(0 \%)$ and boric acid-doped additives (BA2, BA4 ve BA6) at different ratios are shown in Figure 6.
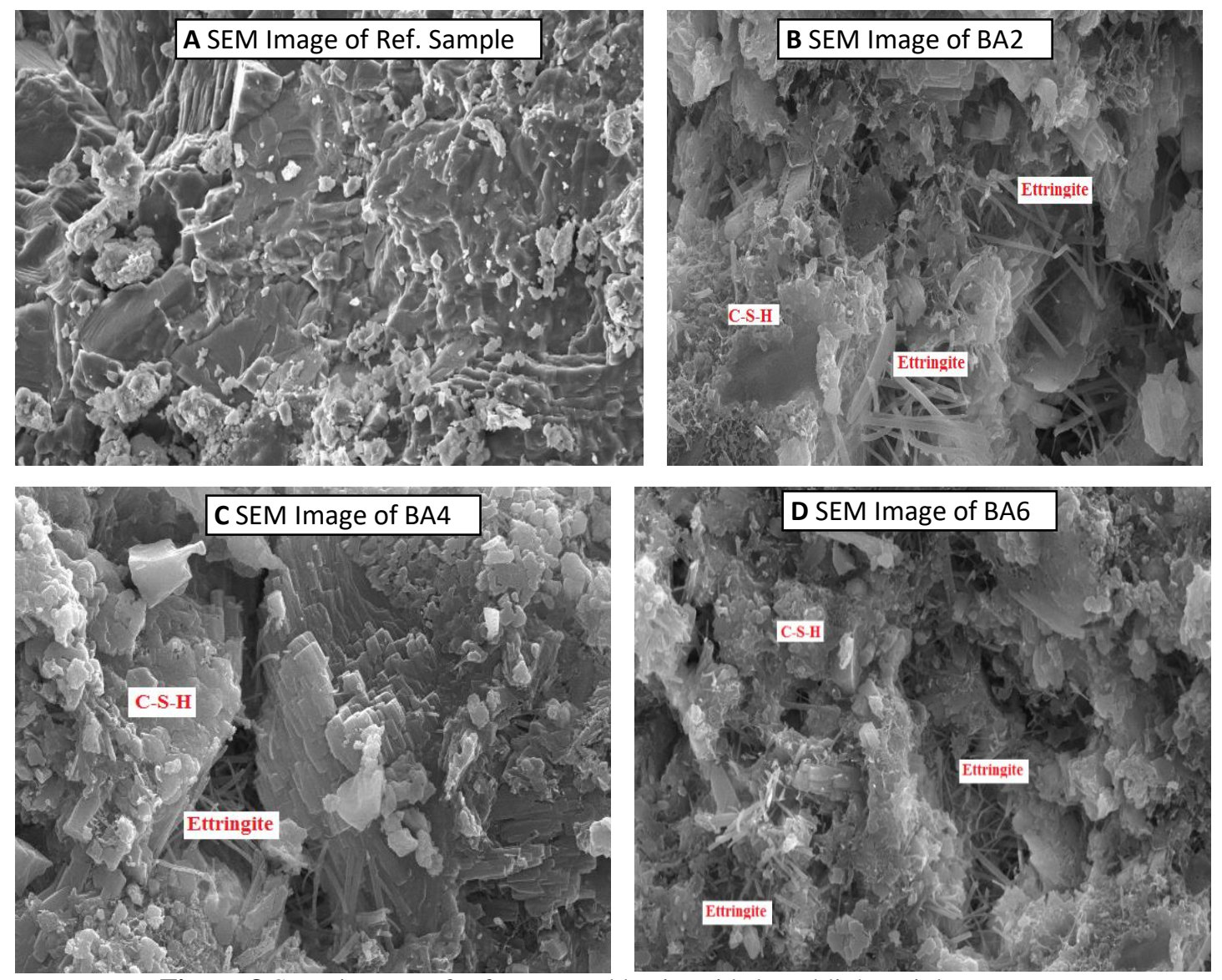

Figure 8 SEM images of reference and boric acid-doped lightweight concretes

When the SEM images of boric acid-doped samples are examined, it is observed that they have fibrous, regular, micro-pored and grain structure. It is observed that the grains seen in the crystal structure of the material are very thin layered and homogeneous leaf-like structures. Generally, it was determined that when the amount of boric acid increases, crystal structures also increase. In their study, Çınar et al. (2014) reported that the substitution of boric acid addition at certain ratios enhances the crystal structure. They stated that otherwise it would make the material structure amorphous. It was seen that boric acid amount did not make the structure of samples amorphous, on the contrary it supported their crystal structures. It was Also, observed that there could be found in globule crystal structures as well as layer-like crystal structures within all boric acid doped samples. As a result of all images examination, it was observed that the best structure was obtained from $6 \%$ boric acid-doped samples a. Considering the other properties of samples of produced lightweight concrete, it was determined that SEM images taken supports the findings of this study [30].

\section{Conclusion}

According to the datas obtained as results of performed tests within the experimental works of this study, when boric acid amount was increased in lightweight concrete samples, the dry unit weight also increased, whereas water absorption and porosity values decreased. Decreasing of porosity values shows that pore ratio within lightweight concrete also decreased. 
As a result of performed compressive strength test for the determination of mechanical properties of produced lightweight concrete samples, the best results were obtained from boric acid additive at $6 \%$ ratio. Also, in parallel with the increment of boric acid amount, the compressive and tensile splitting strengths also increased.

When SEM images taken for structural characterization determination were examined, it was observed that the reference samples had porosity, macro-porous and disordered crystal structure. In parallel with the increase of boric acid amount in boric acid doped samples at \%2,\%4 and \%6 ratios, it was determined that the crystal structure of samples increased. This increase caused a layer-like internal structure of samples transforming into a globule structure. At the same time, it was observed that lightweight concrete samples with boric acid doped at \%6 ratio had more outstanding structural characteristics than other samples.

It was seen that produced reference samples and boric acid doped samples at $2 \%$ ratio could be used in partition block or block for insulation purposes in structures.

As a result of this study, it was seen that boric acid improved the properties of lightweight concrete, furthermore there was no disadvantage in using it in the specified ratios.

\section{Conflict of interest}

The authors declare that they have no conflict of interest.

\section{References}

[1] M. Gül, Investigation of the Use of Waste Plastics and PET, Firat University, 2018.

[2] M.A.B. Emon, T. Manzur, N. Yazdani, Improving performance of light weight concrete with brick chips using low cost steel wire fiber, Constr. Build. Mater. 106 (2016) 575-583. doi:10.1016/J.Conbuiltmad.2015.12.165.

[3] O. Şimşek, Concrete and concrete technology, Seçkin Publications, Ankara, 2007.

[4] M. Hassanpour, P. Shafigh, H. Bin Mahmud, Lightweight aggregate concrete fiber reinforcement - A review, Constr. Build. Mater. 37 (2012) 452-461. doi:10.1016/j.conbuildmat.2012.07.071.

[5] S. Yazıcıoğlu, N. Bozkurt, The investigation of the mechanical properties of structural lightweight concrete produced with pumice and mineral admixtures, Gazi Üniversitesi Mühendislik Mimar. Fakültesi Derg. 21 (2013) 675-680.

[6] B. Vakhshouri, S. Nejadi, Size effect and age factor in mechanical properties of BST Light Weight Concrete, Constr. Build. Mater. 177 (2018) 63-71. doi:10.1016/J.CONBUILD MAT. 2018. 05.115 .

[7] B. Vakhshouri, S. Nejadi, Mix design of light-weight self-compacting concrete, Case Stud. Constr. Mater. (2016). doi:10.1016/j.cscm.2015.10.002.

[8] K. Çakır, Ö., A.; Yoğurtçu, E.; Ramyar, Self-compacting lightweight aggregate concrete: design and experimental study, Mag. Concr. Res. 61 (2009) 519-527.

[9] E. Güneyisi, E.; Gesoğlu, M.; Booya, Fresh properties of self-compacting cold bonded fly ash lightweight aggregate concrete with different mineral admixtures, Mater. Struct. 45 (2012) 18491859.

[10] İ.B. Topçu, Concrete Technology, Uğur Offset co., 2006.

[11] Y. Xu, L. Jiang, J. Xu, Y. Li, Mechanical properties of expanded polystyrene lightweight aggregate concrete and brick, Constr. Build. Mater. 27 (2012) 32-38. doi:10. 1016/ j. conbuildmat.2011.08.030.

[12] S. Aydın, Development of a high-temperature-resistant mortar by using slag and pumice, Fire Saf. J. 43 (2008) 610-617. doi:10.1016/j.firesaf.2008.02.001. 
[13] A. Beycioglu, M.E. Arslan, O.S. Bideci, A. Bideci, M. Emiroglu, Bond behavior of lightweight concretes containing coated pumice aggregate: hinged beam approach, Comput. Concr. 16 (2015) 909-918. doi:10.12989/CAC.2015.16.6.909.

[14] S. Bideci, Ö., The effect of high temperature on lightweight concretes produced with colemanite coated pumice aggregates, Constr. Build. Mater. 113 (2016) 631-640. doi:https: //doi. org/ 10. 1016/j.conbuildmat.2016.03.113.

[15] A.M. Hameed, B.A. Fatah Ahmed, Employment the plastic waste to produce the light weight concrete, Energy Procedia. 157 (2019) 30-38. doi:10.1016/j.egypro.2018.11.160.

[16] L.S. Hooi, P.J. Min, Potential of Substituting Waste Glass in Aerated Light Weight Concrete, Procedia Eng. 171 (2017) 633-639. doi:10.1016/j.proeng.2017.01.398.

[17] L. Attanasio, A.; Largo, A.; Alvarez, I.L.; Sonzogni, F.; Balaceanu, Sustainable aggregates from secondary materials for innovative lightweight concrete products, Heron. 60 (2015) 5-25.

[18] Y. Senhadji, G. Escadeillas, A.S. Benosman, M. Mouli, H. Khelafi, S. Ould Kaci, Effect of incorporating PVC waste as aggregate on the physical, mechanical, and chloride ion penetration behavior of concrete, J. Adhes. Sci. Technol. 29 (2015) 625-640. doi:10. 1080/ 01694243 .2014.1000773.

[19] A. Demirbaş, S. Karslioğlu, The effect of boric acid sludges containing borogypsum on properties of cement, Cem. Concr. Res. 25 (1995) 1381-1384. doi:10.1016/0008-8846(95)001305.

[20] D. Koumpouri, G.N. Angelopoulos, Effect of boron waste and boric acid addition on the production of low energy belite cement, Cem. Concr. Compos. (2016). doi:10. 1016/ j.cemconcomp.2015.12.009.

[21] Ö. Bideci, Investigation of The Physical and Chemical Properties of Boron-Coated Ligthweigth Aggregate Concrete, Trakya University, 2013.

[22] K. Kunt, Utilisation of Borjips which is Boric Acid Tail, Y1ldı Technical University, 2016.

[23] TSE, TS 2511, “Mix designs of load-bearing lightweight concretes,” 2017.

[24] A. Aky1ldız, Investigation of Usability of Boric Waste as a Pozzolanic Material In Production Of Concrete, Namik Kemal University, 2012.

[25] M. Öztürk, Investigation of Physical and Mechanical Properties of Pumice and Perlite Containeng Lightweight Concrete, Namik Kemal University, 2012.

[26] ACI, ACI 213R-87, "Guide for Structural Lightweight Aggregate Concrete, 1999.

[27] A.H. Akçakale, Investigation of Some Strength Characteristics of Bazaltic Pumice And Bims Aggregate Lightweight Concrete, Kahramanmaraş Sütçü İmam University, 2010.

[28] K.M.A. Hossain, Blended cement and lightweight concrete using scoria: mix design, strength, durability and heat insulation characteristics, Int. J. Phys. Sci. 1 (2006) 5-16.

[29] T. Dikici, An investigation on Mechanical Properties of Structural Lightweight Concrete, Dokuz Eylül University, 2010.

[30] E. Çinar, S. Koçyiğit, A. Aytimur, İ. Uslu, A. Akdemir, Synthesis, Characterization, and Thermoelectric Properties of Electrospun Boron-Doped Barium-Stabilized Bismuth-Cobalt Oxide Nanoceramics, Metall. Mater. Trans. A. 45 (2014) 3929-3937. doi:10.1007/s11661-0142343-9. 